\title{
Recognition and indigenizing official statistics: Reflections from Aotearoa New Zealand and Australia
}

\author{
Tahu Kukutai ${ }^{\mathrm{a}, *}$ and Maggie Walter ${ }^{\mathrm{b}}$ \\ ${ }^{a}$ National Institute of Demographic and Economic Analysis, New Zealand \\ ${ }^{\mathrm{b}}$ University of Tasmania, Tasmania, Australia
}

\begin{abstract}
In First World colonised nations such as Aotearoa New Zealand and Australia, population statistics form the evidentiary base for how Indigenous peoples are known and 'managed' through state policy approaches. Yet, population statistics are not a neutral counting. Decisions of what and how to count reflect particular assumptions about Indigenous identity, ways of life and wellbeing. More often than not, the requirements and priorities of government take precedence over the informational needs and priorities of Indigenous communities. Whereas National Statistics Offices (NSOs) once rendered Indigenous peoples invisible in official statistics through non-recognition, the more pressing problem in the 21 st century is that of misrecognition. In seeking to move beyond statistical misrecognition, we propose a set of guiding principles for bringing government reporting frameworks and Indigenous concepts of identity and wellbeing into closer proximity. We argue that a principled approach to collecting, disseminating and analysing Indigenous data not only avoids misrecognising Indigenous peoples but enhances the functionality of official statistics for Indigenous peoples and NSOs alike.
\end{abstract}

Keywords: Indigenous, official statistics, wellbeing, New Zealand, Australia, Māori, Aboriginal and Torres Strait Islander

\section{Introduction}

Globally, there are an estimated 370 million Indigenous peoples spanning all of the world's continents and comprising thousands of unique language and cultural groups. Although the particularities of Indigenous economic, social and cultural conditions vary greatly across countries and regions, the association between indigeneity and structural disadvantage is ubiquitous. Indigenous peoples have among the poorest health and economic outcomes in their homelands, the legacy of colonialism and, in many cases, ongoing oppression and discrimination [1-3]. Australia and Aotearoa New Zealand are no exceptions to this grim Indigenous positioning and, as wealthy colonial settler states, have long used population statistics as the evidentiary base

\footnotetext{
*Corresponding author: Tahu Kukutai, National Institute of Demographic and Economic Analysis, New Zealand. E-mail: tahuk@ waikato.ac.nz.
}

for how Indigenous peoples are known and 'managed' through state policy approaches. While official statistics are discursively positioned as a universal and efficient mode of objective and scientific inquiry, Indigenous population statistics and the categories that inform them are not value neutral. Such data emerge from, and are given meaning through, the dominant frameworks of the settler state societies that produce and use them [4-9]. Decisions on what data are collected, on whom, when, how, and in what format, are not simply matters of administrative choice. Rather they are social, cultural and political artifacts with the power to define and exclude [8]. This claim is more than semantics. Official statistics have a lived impact for Indigenous peoples in both Aotearoa and Australia; from perceptions of who we are, to the policy outcomes derived from those statistics.

Critiques of Indigenous official statistics have a dual character, both of which are germane to this paper [5-79, 19]. On the one hand, there is a strong focus on the need to identify and remedy the shortcomings 
of prevailing concepts, processes and practices. These include the tendency to focus on Indigenous 'problems' rather than strengths; the positioning of Indigenous outcomes vis-à-vis those of the non-Indigenous majority; the consistent undercounting of Indigenous populations; and the exclusive privileging of government information needs. The less developed, but perhaps more important, critique pertains to the failures arising from the silences and omissions within Indigenous population statistics. These include a failure to prioritise or respond to Indigenous needs and aspirations; a failure to move beyond consultancy in Indigenous engagement; a failure to fully recognise Indigenous population diversity and, most crucially, a failure to recognise Indigenous culture, values and practices in the measures used to quantitatively gather Indigenous data.

Since the mid-1990s, Statistics New Zealand (SNZ) and the Australian Bureau of Statistics (ABS) have heard at least some of these critiques. Both have developed a range of policy and procedures, largely built around a commitment to increase engagement with their Indigenous constituencies [20-22]52]. In Aotearoa, the Māori Statistics Framework [23] and the inaugural 2013 Māori Social Survey known as Te Kupenga [24] are aimed at producing statistics that are 'for Māori' rather than simply 'about Māori'. In Australia the ABS has recently developed an Aboriginal and Torres Strait Islander Statistics Program [21] and established an Aboriginal Reference Group. Nevertheless, in both countries, established practices with respect to the collection, production and dissemination of Indigenous population statistics remain largely intact. This lack of substantive change is more than a tendency towards bureaucratic inertia. Rather, we argue, the continuation of the status quo arises from a deep ontological and epistemological divide on what Indigenous statistics could and should be. This divide centres around the concept of statistical functionality that is, the functionality of Indigenous official statistics for users. In this paper we ask the question: For whom are Indigenous statistics functional; for what purpose; and in what context?

Our central claim is that there is a recognition gap separating what Indigenous statistical functionality means for Indigenous scholars and peoples, and how it is understood by National Statistical Offices (NSOs). This conceptual disconnect is a formidable barrier to building effective interaction between NSOs and Indigenous peoples, not only in Aotearoa and Australia, but more widely. In Aotearoa this gap in the un- derstanding of Indigenous statistical functionality has led various iwi (tribes) and Māori organisations to undertake their own data collection projects [14|25|26]. Similarly, in Australia, frustration with official statistics has led the Yawuru people in Western Australia to commission the Knowing our Community survey [14, [18|27]. Yet for various reasons, not the least of which is the need to maintain visibility, opting out of official statistics is not an option. Instead, finding ways to indigenize the SNZ and the ABS, in tandem with building robust statistical practices within indigenous communities, offers a more fruitful path forward.

In attempting to bridge the dual understandings of statistical functionality, we use Taylor's [16] model of translation in the 'recognition space'. The recognition space is the small intersect between Indigenous cultural values and practices concerning wellbeing; and government reporting frameworks and concepts. As Taylor argues, it is in this space "where policy makers and Indigenous peoples can seek to build meaningful engagement and measurement' [16, p. 116]. Taylor's concept draws more broadly on recognition theory [19]28]29] and aligns with recent scholarship on the misrecognition of Indigenous identities in the context of legal and bureaucratic structures. Andersen [4] for example, has used the term 'miscrecognition' to describe how the social, legal and statistical construction of Métis as Canada's 'mixed race' population has made it difficult for them to make political claims as an Indigenous people. Whereas NSOs in Aotearoa and Australia once rendered Indigenous peoples invisible in official statistics, we argue that the more pressing problem now is one of misrecognition.

Drawing on the concepts of recognition and misrecognition, we illustrate the slippage between statistical functionality for Indigenous peoples as it currently operates, and how it could be. We begin our discussion with a brief overview of Indigenous official statistics in both countries then propose a set of five guiding recognition principles that might bring government reporting frameworks and Indigenous concepts of wellbeing into closer proximity. In so doing we hope to stimulate an ongoing dialogue on the changes needed to improve statistical functionality for Indigenous peoples.

\section{Non-recognition, misrecognition and Indigenous statistics in Aotearoa and Australia}

\subsection{Australia}

Until amended by referendum in 1967, Section 127 of the Australian Constitution specifically excluded the 
'aboriginal race' from official population figures [30]. Even after the 1901 Constitutional exclusion, however, data on Aboriginal populations were collected but not included in formal Census counts [31]. Enumeration of Aboriginal populations functioned as a form of state surveillance, monitoring the presumptive 'dying race' status of Aboriginal and Torres Strait Islander peoples [32]. Indeed, the notion that Aboriginal people would disappear persisted until as recently as World War II [31].

The 1971 Australian National Census of Housing and Population was the first five yearly Census to include Indigenous Australians in the population totals and to do so on the basis of self-identification [33]. Notwithstanding the deeply problematic notion of a single Aboriginal and Torres Strait Islander population, national collections beyond the Census rarely contained a valid Indigenous sample. The failure of agencies to consistently ask Indigenous status and the inaccurate recording of such status produced a legacy of systematic undercounting of Indigenous peoples in administrative data collections. Most national surveys are not specifically targeted to Indigenous peoples and contain only a small number of Aboriginal and Torres Strait Islander peoples, thus magnifying the likelihood of statistical error. Even within the Census, the undercounting of Aboriginal and Torres Strait Islander peoples has been substantial. In 2006 the estimated Indigenous undercount was 11.5 per cent, more than four times the national undercount of 2.7 per cent. Despite additional funding and targeted efforts, the Indigenous undercount in 2011 increased to 17.2 per cent while the national undercount reduced to 1.7 per cent [34]. While some of the increase in the Indigenous undercount has been attributed to improvements in the Post Enumeration Survey, such a sizeable gap remains unacceptable.

The lack of policy-relevant Indigenous data is an enduring problem, having been identified in the 1991 Royal Commission Into Aboriginal Deaths in Custody (RCIADIC) [35]. Partly in response to the commission's findings, the ABS developed the cross-sectional National Aboriginal and Torres Strait Islander Social Survey (NATSISS), which was the first specific Indigenous data collection exercise in Australia. NATSISS data collection was undertaken in 1994, 2002, 2008 and 2014. The design and implementation of the 2014 NATSISS is a good example of the functionality gap that persists in Indigenous statistics. The seven core objectives of NATSISS clearly signal that the survey is first and foremost about meeting the government's informational needs. The first three objectives are primarily about ensuring the usefulness of the data to government agencies in order to fulfill their functions (e.g., providing estimates at national, state/territory and remoteness levels). The other four objectives focus on disadvantage and social inclusion, and the data needed to report on and monitor the government's social inclusion agenda. The lack of consideration given to Indigenous objectives not only signifies that the needs of government are the priority, but that prioritization is to the exclusion of the needs and interests of Aboriginal and Torres Strait Islander peoples.

In terms of its purpose, NATSISS exists to facilitate the monitoring of Indigenous social wellbeing yet we already know Aboriginal and Torres Strait Islander peoples are heavily over-represented on every negative socio-economic indicator. More data collection may answer government questions relating to the closure, or otherwise, of the statistical socio-economic gap, but little else. From an Indigenous perspective the wrong research (as opposed to survey) question is being asked. What then might be the right research question? Gray [36] articulates two options: to provide information on the distinctive nature of Indigenous Australian lives, aspirations and experiences; and to empower Indigenous communities by providing information which can be used to plan, and advocate for the changes needed to improve lives.

Likewise, the relentless focus on documenting problems also seriously undermines the statistical functionality of NATSISS for Indigenous peoples. Over the last 20 years, the context of the Aboriginal relationship to, and position within, broader Australian society has changed substantially. What was (perhaps) appropriate for 1994 is anachronistic in 2015. Indigenous Australia has changed but the context of NATSISS has not. The failure to adapt to new Indigenous life space realities is reflected in the fact that the survey itself has changed little in 20 years. Moreover, the data are primarily descriptive with most topics, especially those important to Indigenous Australians, addressed only superficially, leading to Gray's [36] labeling of the survey as 'A mile wide, inch deep'.

The issues identified above, a focus on government rather than Indigenous needs, a lack of questions or modules related to Indigenous perspectives or aspirations, an over-emphasis on issues of disadvantage and a descriptive rather than explanatory approach, has reduced the perceived relevance of NATSISS for Aboriginal and Torres Strait Islander peoples and researchers. This perception is unfortunate, given the wealth of data 
that is does and could contain. However, until NATSISS is perceived as data for us rather than about us, its relevance will remain under-developed.

\subsection{Aotearoa New Zealand}

In Aotearoa the historical legacy of Indigenous statistics is one of population data collected in service of evolving state efforts to civilise, assimilate and integrate Māori. In the late 19th and early 20th centuries the statistical interest in Māori-European 'half-castes' was clearly linked to colonial policies of racial amalgamation whereby the increasing ratio of half-castes to Māori 'full-bloods' served as an important indicator of success [5]. As was the case in Australia, this prediction proved misguided. Māori are now unique amongst Indigenous peoples in the colonial settler states in comprising a relatively large share of the overall population, at around 15 per cent [22]. Although comparable in terms of absolute size, the Māori proportion far exceeds the 2.5 per cent Indigenous share of the total Australian population enumerated in the 2011 Census 1 In terms of contemporary practice, SNZ has tended to be more proactive than the ABS in trying to address the statistical needs of its Indigenous peoples. While this might be partly due to the higher demographic visibility of Māori, it also reflects deeper differences in forms of political and social exclusion. Māori voting rights, for example, preceded Aboriginal rights by at least 80 years, depending on the state. Decades of efforts by Māori researchers and community leaders to change how Māori data are collected and disseminated has also created important pressure points for change [37/38].

In recent years SNZ has signaled that it wants to move away from a model of simply collecting data about Māori, to collecting data that is for Māori, and this is reflected in its policies. One outcome has been the development of the inaugural Māori Social Survey, Te Kupenga. Conducted after the 2013 Census, Te Kupenga represents a significant step forward in SNZ's attempts to respond to Māori wishes for high-quality data on cultural practices and institutions. As a postcensal survey, Te Kupenga has generated nationally

\footnotetext{
${ }^{1}$ The 2013 New Zealand Census enumerated 598,602 persons who identified as Māori by ethnicity (intended as a cultural definition) and 643,977 persons who identified as Māori by descent. The difference reflects nuances in how Māori identity in the Census is understood and expressed. In the 2011 Australia Census, 548,368 persons identified as an Aboriginal or Torres Strait Islander.
}

representative data that can be linked to Census records to provide a powerful evidence base on Māori social, economic and cultural wellbeing. The dissemination strategy has also been promising, with the first release data adopting a strengths-based approach in relation to indicators of cultural identity, whānau (family) wellbeing, wairua (spirituality) and engagement with Māori networks, customs and language [24]. Te Kupenga data are being used in a variety of policy settings including the government's Families and whānau status report; the local government-focused Māori Plan in Auckland, and various SNZ informational products.

In a practical sense, however, significant challenges remain with respect to making official statistics functional for Māori. One is the lack of a long-term commitment for Te Kupenga. While the budget for the 2018 Census was confirmed in 2014, there has yet to be a formal announcement on whether a second iteration of the post-censal survey will be funded. The uncertainty around future iterations of Te Kupenga means that it risks becoming a special 'one off' survey rather than a lasting commitment to meeting Māori statistical needs. There are also issues with data quality and community engagement mechanisms. These include the doubling of the Māori net undercount in the 2013 Census (6.1 per cent compared to 3.1per cent in 2006) [3940]; the reduction in the number of Māori liaison officers providing a vital link into Māori communities; and the disbanding of the Māori Statistical Advisory Group to the Government Statistician in 2014. The apparent lack of attention given to Māori statistical needs in the context of SNZ's Census transformation programme has also raised concerns. The transformation options include a shift from a five-year to a tenyearly Census, and the replacement of the full enumeration survey model with an administrative Census [41]. In the latter case, the poor quality of ethnicity data collected in administrative data collections is a particular issue for Māori. A recent SNZ study that used administrative data to generate sub-national population estimates found that only 65 per cent of individuals had an ethnicity recorded, which precluded the production of sub-national estimates for Māori as part of that exercise [42].

With the foregoing critiques in mind, we next identify five key recognition principles that we believe will help NSOs address the challenge of achieving statistical functionality for Indigenous peoples. In doing so we draw on our collective experiences as Indigenous social scientists who use official statistics for Indigenous-focused research, as well as our experiences serving as members of Indigenous advisory committees to our respective NSOs. 


\section{Towards a Recognition Framework for indigenizing official statistics}

\subsection{Recognising geographic diversity}

The first recognition principle relates to the welldocumented importance of place for Indigenous peoples. As Taylor [7] and Yu [18] have argued persuasively, the geographic, social and cultural spaces invoked through official statistics, and relatedly through policies and demographic research, are of limited relevance to Indigenous peoples. The default to national scales and other administratively defined spatial boundaries tends to mask, and even distort, dynamics within and across local communities, particularly in remote areas. For Aboriginal and Torres Strait Islander Australians, national, state or remoteness level data disaggregation have been the default categories used to define Indigenous spatiality. Recognising this, a new geographic classification, the Australian Indigenous Geographic Classification, was recently introduced to improve the relevance of spatial data for Indigenous communities but its effectiveness remains to be seen. The emphasis on remote demography in official statistics is also at odds with the lived experience of many Indigenous Australians, with three out of every four Aboriginal and Torres Strait Islander people residing in urban and regional areas.

For Māori, there are important issues around data disaggregation pertaining to iwi or tribes. As more iwi have reached financial settlements and moved into development mode, their governance bodies have expressed an urgent need for timely, relevant and accurate data about their people [25]. Current statistical practices offer little disaggregation flexibility. While SNZ compiles basic iwi profiles from each Census, access to more detailed data is restricted and can incur significant costs. Some commentators have questioned whether iwi data should be exclusively owned and controlled by the government [38]. For some iwi authorities, the official Statistical Classification of Iwi is illsuited because the classification constitutes iwi populations with little regard for the legislative definitions that iwi must adhere to. In addition, the iwi question in the Census is based entirely on self-report and is thus distinct from the concept of registered or enrolled tribal status. The result for some iwi is a significant mismatch in the size and characteristics of their population in the Census compared to their tribal register [25].

Likewise, the spatial units and classifications used to aggregate meshblock data cannot be readily mapped onto tribal rohe (customary boundaries). This lack of flexibility poses a significant barrier for tribal and place-based Māori groups seeking information about themselves. The relatively simple question, 'What proportion of our people lives in our customary boundaries?' can only be answered indirectly through aggregating administrative units such as Territorial Authorities. Given that the vast majority of Māori in New Zealand (85 per cent) live in urban areas, and at least one in six Māori lives outside of New Zealand [43], such a question goes to the heart of Indigenous statistical functionality.

\subsection{Recognising cultural diversity}

Various scholars have identified the tendency of official statistics to frame Indigenous peoples as ethnic or racial minority populations with 'special' needs, rather than rights-bearing peoples with a distinctive status that is recognised internationally [44]. In Aotearoa the majority of statistical and policy formulations continue to frame Māori as an ethnic group despite the expansion of census definitions in 1991 to include ancestry and iwi identification [5]. In Australia, Indigenous data are what Altman [19, p. 193] refers to as a 'by-product of including an Indigenous identifier'. Changes of wording of the 'Indigenous' question have occurred since 1971 but there remains no further interrogation of Indigeneity other than asking if the person is of Aboriginal or Torres Strait Islander origin. Although reporting of Indigenous languages spoken by respondents has recently been added to some data reporting, the rapidity of colonisation and social destruction means that few Indigenous Australians from nonremote areas speak their own language.

As yet there are no population data collected to count or portray the more than 500 distinct Aboriginal nations that make up the Australian Indigenous population (e.g., Warlpiri, Wiradjuri, Palawa, Yorta Yorta, Yolngu), each of whom has their own unique history, affiliation to country and cultural identity [45]. In Western Australia, for example, we know that the Noongar people are the traditional owners of the country where the city of Perth is now situated. We also know that 1.6 per cent of the population of Perth identified as Aboriginal in the 2011 Census. But there is no way of knowing how many of those people are Noongar, nor what their demographic profile and socioeconomic circumstances are. Yet such data are of real importance to the Aboriginal peoples of the area in their current negotiations over native title claims with the Western Australian Government [46]. 


\subsection{Recognising other ways to know us}

Zuberi and Bonilla-Silva note that statistical data do not tell a story of themselves. Rather, the data are used to 'craft a story that comports with our understanding of the world' [47, p. 7]. For Māori and Aboriginal and Torres Strait Islander people, the story being told rarely comports to our own worldview but more likely reflects the limited and/or erroneous understanding of who we are by the non-Indigenous majorities who produce and engage with official statistics. In a circular process, the more the story of the data are told from a non-Indigenous standpoint, the more evidence there is embed that worldview as 'the truth'. The result goes beyond mere differences in terms of statistical stories and interpretations. Statistical categorisations play an important part in cementing a symbolic ethnic and racial order, and the ways in which indigenous identities are framed has particular consequences for how such hierarchies are maintained.

The scholarship of Indigenous academics provides clear pointers on how to realise alternative framings

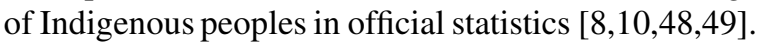
One is to position Māori and Aboriginal and Torres Strait Islander people as rights bearing indigenous peoples rather than as disadvantaged, but otherwise undifferentiated, ethnic or racial minorities. How indigenous peoples are framed can occur at various points in the data process; from high-level principles embedded in official documents, to the nomenclature and categories; and in the dissemination of official data in public reports, media releases. Deficit oriented approaches that frame Indigenous peoples as a problem to be solved (even if implicitly), also need to be replaced with strengths-based approaches which are more readily amenable to identifying and enabling mechanisms for change. This does not mean ignoring structural inequalities in health, education, incarceration and so forth. Rather, it means changing the ways in which forms of inequality are described and interpreted. Too often contemporary forms of inequality are decoupled from the unequal institutional arrangements that structure the relationships between Indigenous peoples and the State. The prescribed policy solution thus becomes one of changing individual Indigenous behaviours and orientations (e.g., to lead healthier lifestyles, develop greater labour market attachments), rather than addressing the fundamental power inequalities that continue to designate many Indigenous peoples as second class citizens in their own homelands. The section on determinants of health and welfare described in the 2011 edition of The Health and Welfare of Australia's Aboriginal and Torres Strait Islander People is a primary example. Despite research that finds Aboriginal people are the poorest people in Australia, regardless of geographic location [45], there is no exploration of Aboriginal poverty as a structural issue. Rather, the section merely presents data about Indigenous 'problems' including low school retention rates, poor housing, and behavioural issues.

The foregoing critiques are encapsulated in the default analytical norm, in Aotearoa and Australia, of comparison with data from the non-Indigenous population. Māori and Aboriginal Australians are internally diverse with regards to demographic characteristics, class, country and identification with group norms and symbols [5 48 50]. The use of indigenous/nonIndigenous connotes a false sense of internal homogeneity. More critically the ordinariness of this dichotomisation into Indigenous/non-Indigenous comparisons masks its inherent potential to underpin pejorative discourses of Indigenous lived reality. They imbue the analytical frame with a subtle, but entrenched depreciatory tone, rating the problematic Indigenous 'other' against the 'normal' New Zealander or Australian [9]. Indigenous statistics, functional for Indigenous peoples, would tell a very different story of who we are as contemporary Māori and Aboriginal and Torres Strait Islander people.

\subsection{Recognising the need for mutual capability building}

Capacity building around statistical literacy within Māori and Aboriginal and Torres Strait Islander communities is recognised by official statistics agencies in both countries. What is not as well recognised is the need to capacity build non-indigenous staff and analysts to appreciate the impact of their own worldview on how they understand Indigenous statistical functionality [8]. In so far as NSOs have sought to internally transform their own practices, the emphasis has been on building 'cultural awareness' or, more latterly, 'cultural competence' in Indigenous culture. For example, the ABS Reconciliation Action Plan 2013-2016 Objective 4 is for ABS employees to develop appropriate cultural competency skills [51]. SNZ has developed similar initiatives as part of an organisational shift that resulted in the disbanding of the dedicated Māori statistics unit (with some very experienced and excellent Māori researchers), and a greater push to embed Māori responsiveness across all parts of the organisa- 
tion. Such training can produce useful outcomes if it expands the recognition space towards a more indigenized conception of statistical functionality. This is unlikely to happen, however, unless those who produce Indigenous statistics also develop a robust understanding of the how their understanding of statistical functionality is deeply embedded in their social and cultural milieu. Cultural competence not only involves the capability to comprehend diverse cultural viewpoints and apply them within one's own practice, but also involves an awareness of one's own cultural assumptions and values.

Building statistical capability in Indigenous communities is also key. For Indigenous organisations and communities there is little point in pouring a great deal of effort into changing how data are categorised, collected and disseminated within NSOs if there is no capability to engage with those data on our own terms. In Aotearoa the loosening of restrictions around accessing unit-level data from the Census and integrated administrative datasets provides a good example of how simply collecting the 'right' data and making it available will not, on its own, ensure genuine statistical functionality for Indigenous peoples. While easier and cheaper access to unit-level data has been warmly welcomed by the research community generally, it is unlikely to make much difference to Māori if there is no sustained effort to expand the very small pool of Māori researchers with the requisite statistical expertise or experience to use them.

\subsection{Recognising indigenous decision making}

The fifth and arguably most important principle that underpins this paper is the principle of autonomy and self-determination. This is not a trifling matter. As Taylor [7]16] and others have noted [14], rights of selfdetermination have been given institutional form internationally through the United Nations Declaration on the Rights of Indigenous Peoples (UNDRIP) [44], and have implications for the collection and administration of statistical data. Articles 18, 19 and 23 of UNDRIP are of particular relevance for statistical reporting frameworks, while the overall focus of the Declaration on rights of Indigenous 'peoples' as opposed to 'populations' adds a further dimension. These Articles refer to rights to participate in decision-making through Indigenous institutional structures on matters affecting Indigenous peoples; they demand of States good-faith consultation based on the principle of free, prior and informed consent, and they insist on Indige- nous priority setting in regard to what constitutes development [14].

Currently neither ABS nor SNZ make any meaningful concession to this principle. Indigenous peoples in both contexts remain peripheral to the main channels of power through which consequential decisions about Indigenous statistics are made. Consulting with a limited and selective list of Indigenous stakeholders and having an Indigenous advisory committee that meets infrequently and without any binding power, does not constitute autonomy, or any genuine attempt at powersharing. Effective participation means participation in decision-making. Yet, as it stands, Māori and Aboriginal and Torres Strait Islander peoples remain largely marginalised from the design, production and use of Indigenous data.

In Aotearoa, the Effectiveness for Māori (EM) strategy makes references to enabling effective Māori participation in planning and decision-making, but offers no guidance for what enabling structures might be put in place, nor how effective participation might be monitored [52]. The EMS also recognises the need to address '... internal systemic barriers to the production of statistics for Māori'. This is heartening in so far as it constitutes an admission that cultural and procedural barriers to meeting Māori statistical needs exist within the organisation, and that is not simply a matter of educating Māori to realise the value of official statistics (another goal outcome), or fixating on technical issues relating to measurement.

But missteps continue to be made that reinforce the lack of a recognition of right for Māori autonomy and genuine participation in decision-making. Measures such as the EM strategy are to be commended but, when situated within the institution's broader strategic goals outlined in Statistics 2020 - Te Kāpehu Whet $\bar{u}$, it is clear that much of the new direction is driven by broader institutional goals. These include realising greater value across the official statistics system; transforming the delivery of statistics; and creating a customer-focused, sustainable organisation [53]. Responsiveness to Māori is but one part of a much broader strategic plan to remain relevant and sustainable amidst rapid technological change. In addition, it is clear that economic imperatives have provided a good deal of impetus for SNZ to rethink their strategy towards Māori. Various documents make reference to the importance of the post-settlement context (e.g. [36]), and there has been a strong interest, both within government agencies and among key Māori economic actors, in measuring and monitoring what 
has become known as the Māori Economy. The recent release of Tatauranga Umanga Māori, a framework for measuring the economic activities of Màori authorities, is the first stage of a larger initiative to quantify Māori economic activities and collectively owned assets [54].

In Australia, despite a history of official Indigenous statistics that now spans 40 years, those involved with the commissioning, development, analysis and interpretation of official statistics remain almost totally non-Indigenous. Over time there has been a rising level of consultation with Aboriginal and Torres Strait Islander people. For example, the 2014 NATSISS collection was informed by the Aboriginal and Torres Strait Islander Round Table of prominent community representatives and community consultations in each state. But consultation is not an active word and, in both Aotearoa and Australia, the power to accept or reject consultative advice always remains with the agencies soliciting advice. Indigenous participation in official statistics needs to go beyond being survey respondents.

The ABS has, in recent times, developed a newer Indigenous Community Engagement Strategy with the stated aim of enhancing the ABS's engagement with Aboriginal and Torres Strait Islander communities and organisations [55]. Strategies include the return of information and improving the quality and relevance of Aboriginal and Torres Strait Islander statistics, with the appointment Indigenous Engagement Managers in each state and the Northern Territory [56]. This strategy indicates a willingness on behalf of the ABS to change the way it does Indigenous statistics. A translation from strategy to engagement however cannot be achieved by the ABS alone. A statistical agency/Indigenous partnership is needed; a partnership based on mutual respect and shared power, as well as mutual recognition that there is significant ontological and epistemological space that needs to be traversed for mutual understanding. Assisting NSOs to develop such partnerships is the task of Indigenous scholars and community leaders. Critique is necessary but insufficient. The dual design and provision of community education on the benefits of Indigenous statistics/community-led education for statistics agencies can only be achieved through partnership.

\subsection{Meeting in the recognition space}

Having both identified barriers to achieving Indigenous statistical functionality, and proposed a set of principles for addressing them, we now return to Tay- lor's concept of the recognition space and discuss how this might be productively reforged for the mutual benefit of Indigenous peoples and NSOs. While we acknowledge the efforts made by our respective NSOs to redress some of the issues identified, we nevertheless maintain that we are a way off securing genuine statistical functionality for Indigenous peoples. Over the last two decades NSOs in Aotearoa and Australia have moved from a position of non-recognition of statistical functionality for Indigenous peoples. However, the move has been from non-recognition to misrecognition, particularly in the case of Australia. Despite the use of more appropriate words and phrases, there remains an ontological and epistemological gap in how Indigenous statistics are understood. This gap is demonstrated not only by the inappropriateness of some measures, such as those pertaining to Indigenous geographical diversity, but also a critical divide between Indigenous and non-Indigenous understandings of key concepts. For example, Taylor [7] and others [57] have pointed to the ontologically embedded differences in how the concept of well-being are understood. For Māori and Aboriginal and Torres Strait Islander peoples the concept of well-being goes well beyond individual or even family physical, mental and economic health. Such differences undermine the validity of measures, perhaps to the point of uselessness.

Moving from misrecognition to recognition is a complex process. We argue that the recognition space, where our understandings of Indigenous statistics functionality intersect, is the place to start. A dual occupancy of statistical functionality begins with putting the Indigenous, Māori and Aboriginal and Torres Strait Islander, into Indigenous official statistics. Indigenous people need to be intimately involved as partners. In both nations there is a wealth of Indigenous expertise in the research sector, in community organisations, and as business operators and specialists that is being wasted in out-dated 'consultation' practices. Dual occupancy of recognition space would reinvigorate the currently stagnant space of official Indigenous statistics to include data on Indigenous aspirations, achievements, and what is good about being a Māori, or Aboriginal and Torres Strait Islander person, in our respective nation states today. Crucially, Indigenous official statistics would add directionality. Rather than a one sided non-Indigenous lens on the Indigenous, statistics could embody a two way interaction; providing a feedback conduit to Government of Indigenous views, perspectives and understandings on issues of importance to policy makers, the wider non-Indigenous Australian community, and to other Indigenous people [58]. 


\section{Conclusion}

The objectives of Indigenous peoples, NSOs and government are not incompatible. They can, and should, work together, to inform the agenda and priorities of Indigenous communities and governance organisations, service organisations, scholars and researchers. We argue that expanding the recognition space and improving the functionality of Indigenous statistics requires a number of shifts. These include: a recognition of Indigenous geographic and cultural diversity; a recognition that current ways of conceptualising the data are not the only, or the most useful, set of practices; a recognition of the need for mutual capability building; and most crucially, a recognition of the need for genuine Indigenous decision making to shape the functionality of Indigenous statistics. A principled approach to collecting, disseminating and analysing Indigenous data not only avoids misrecognition but, more critically, enhances the functionality of official statistics for Indigenous peoples and NSOs alike.

\section{References}

[1] M. Cooke, F. Mitrou, D. Lawrence, E. Guimond and D. Beavon, Indigenous well-being in four countries: An application of the UNDP'S Human Development Index to Indigenous Peoples in Australia, Canada, New Zealand, and the United States, MC International Health and Human Rights 7 (9) (2007). doi:10.1186/1472-698X-7-9.

[2] M. Durie, The health of Indigenous peoples: Depends on genetics, politics, and socioeconomic factors, BMJ: British Medical Journal 326(7388) (2003), 510-511.

[3] M. Gracey and M. King, Indigenous health part I: Determinants and disease patterns, Lancet 374 (2009), 64-75.

[4] C. Andersen, Metis: Race, Recognition and the Struggle for Indigenous Peoplehood. Vancouver: University of British Columbia Press, 2014.

[5] T. Kukutai, 'Quantum Māori, Māori quantum: Representations of Māori identities in the census, 1857/8-2006', in: Counting Stories, Moving Ethnicities: Studies from Aotearoa New Zealand, R. McClean, B. Patterson and D. Swain, eds, Hamilton: University of Waikato, 2012, pp. 27-51.

[6] S. Prout, Indigenous wellbeing frameworks in Australia and the quest for quantification, Social Indicators Research, (2011). doi: 10.1007/s11205-011-9905-7.

[7] J. Taylor, Indigenous demography and public policy in Australia: Population or peoples? Journal of Population Research 26 (2009), 115-130.

[8] M. Walter and C. Andersen, Indigenous Statistics: A Quantitative Methodology. Walnut Creek: Left Coast Press, 2013.

[9] M. Walter, The Politics of the Data: How the Statistical Indigene is Constructed, International Journal of Critical Indigenous Studies 3(2) (2010), 45-56.

[10] C. Andersen, From nation to population: The racialisation of Métis in the Canadian census, Nations and Nationalism 14(2) (2008), 347-368.
[11] P. Axelsson, P. Sköld, J. Ziker and D.G. Anderson, From indigenous demographics to indigenous demography, in: Indigenous Peoples and Demography: The Complex Relation Between Identity and Statistics, P. Axelsson and P. Skold, eds, Oxford: Berghan, 2011.

[12] K. Johnstone, Indigenous fertility transitions in developed countries, New Zealand Population Review 37 (2011), 105123.

[13] T. Kukutai, 'Contemporary issues in Māori demography', in: Màori and Social Issues, T. McIntosh and M. Mulholland, eds, Wellington: Huia, 2011, pp. 11-48.

[14] T. Kukutai and J. Taylor, Postcolonial profiling of indigenous populations: Limitations and responses in Australia and New Zealand, Espace Populations Sociétés 1 (2012), 13-27.

[15] E. Peters, Still invisible: Enumeration of indigenous peoples in census questionnaires internationally, Aboriginal Policy Studies 1(2) (2011), 68-100.

[16] J. Taylor, Indigenous peoples and indicators of well-being: Australian perspectives on United Nations global frameworks, Social Indicators Research 81(1) (2008), 111-126.

[17] M. Walter, Using the 'power of the data' within Indigenous research practice, Australian Aboriginal Studies 2 (2005), 2734.

[18] P. Yu, The Power of Data in Aboriginal Hands. CAEPR Topical Issue No. 4/2012. Canberra: Australian National University, Centre for Aboriginal Economic and Policy Research, 2012.

[19] J.C. Altman, 'The 1994 NATSIS: From conception to completion and beyond', in: The 1994 National Aboriginal and Torres Strait Islander Survey: Findings and Future Prospects, J.C. Altman and J. Taylor, eds, Canberra: The Australian National University, Centre for Aboriginal Economic Policy Research, 1996, pp. 1-12.

[20] Australian Bureau of Statistics (2000). Directions in Australia's Aboriginal and Torres Strait Islander Statistics. Australian Bureau of Statistics, Canberra.

[21] ABS (n.d.). Aboriginal and Torres Strait Islander Statistics Program. Canberra: Australian Bureau of Statistics.

[22] Statistics New Zealand. (2013a). 2013 Quickstats about Māori. Wellington: Statistics New Zealand. Accessed online at: http://www.stats.govt.nz/Census/2013-census/profile-andsummary-reports/quickstats-about-M $\bar{a}$ ori-english.aspx.

[23] Statistics New Zealand (2002). Towards a Māori statistics framework: A discussion document. Wellington: Statistics New Zealand. Accessed online at: http://www.stats.govt.nz/ browse_for_stats/people_and_communities/Māori/towardsa-Māori-stats-framework.aspx\#previous.

[24] Statistics New Zealand. (2014a). Te Kupenga 2013 (English) Corrected. Accessed online at: http://www.stats.govt.nz/ browse_for_stats/people_and_communities/Māori/TeKupen ga_HOTP13.aspx.

[25] J. Walling, D. Small-Rodriguez and T. Kukutai, Tallying Tribes: Waikato-tainui in the census and iwi register, Social Policy Journal of New Zealand 36 (2009), 2-15.

[26] Whakatohea Māori Trust Board (2014). He Oranga o Te Rohe o Te Whakatōhea Wellbeing Survey 2010. Accessed online at: http://www.whakatohea.co.nz/whakat\%C5\%8Dhealead-economic-development-opotiki.

[27] J. Taylor, B. Doran, M. Parriman and E. Yu, Statistics for community governance: the Yawuru Indigenous Population Survey of Broome. CAEPR Working Paper No. 82, Canberra: Centre for Aboriginal Economic Policy Research, The Australian National University, 2012. 
[28] N. Fraser and A. Honneth, Redistribution or Recognition? A political-philosophical exchange. London: Verso, 2003.

[29] C. Taylor, 'The Politics of Recognition', in: Multiculturalism and the Politics of Recognition, A. Gutmann, ed., Princeton: Princeton University Press, 1994, pp. 25-73.

[30] J. Chesterman and B. Galligan, Citizens Without Rights, Aborigines and Australian Citizenship. Cambridge: Cambridge University Press, 1997.

[31] G. Briscoe, Counting, Health and Identity: A history of Aboriginal health and demography in Western Australia and Queensland, 1900-1940. Canberra: Aboriginal Studies Press, 2003.

[32] B. Attwood and A. Markus, The Struggle for Aboriginal Rights: A documentary history. Sydney: Allen \& Unwin, 1999.

[33] Australian Bureau of Statistics. (2007). ABS Celebrates 40 years since Aboriginal and Torres Strait Islander people included in population estimates. Media Release May 26. http:// www.abs.gov.au/ausstats/abs@.nsf/mediareleasesbytitle/454 D4207EA2C3FBDCA2572E5007FB33B?OpenDocument.

[34] Australian Bureau of Statistics (2012a). Census of Population and Housing - Details of Undercount, 2011. Cat. No. 2940.0. Canberra.

[35] Commonwealth of Australia, (1991). Royal Commission into Aboriginal Deaths in Custody. National Report, vol. 2. Canberra: Australian Government Printing Services.

[36] M. Gray, 'A Mile Wide. Inch Deep: The future for Indigenous social surveys?' In: Survey Analysis for Indigenous Policy in Australia: Social Science Perspectives, B. Hunter and N. Biddle, eds, CAEPR Research Monograph No. 32. Canberra: ANU E Press, 2012.

[37] C. Mako, Some statistical issues for Māori - definitions and applications, He Pukenga Kōrero 4(1) (1998), 33-41.

[38] B. Robson and P. Reid, Ethnicity matters: Māori perspectives. Wellington: Statistics New Zealand, 2001.

[39] Statistics New Zealand (2014). Post-enumeration survey 2013. Accessed online at: file:///Users/tahu/Desktop/PostEn umerationSurvey13HOTP.pdf.

[40] Statistics New Zealand (2007). A report on the 2006 Postenumeration survey. Accessed online at: file:///Users/tahu/ Downloads/post-emuneration-survey\%20(1).pdf.

[41] C. Bycroft, Options for future New Zealand censues: Census transformation programme. Wellington: Statistics New Zealand, 2013.

[42] S. Gibb and E. Shrosbree, Evaluating the potential of linked data sources for population estimates: The Integrated Data Infrastructure as an example. Wellington: Statistics New Zealand, 2014.

[43] T. Kukutai and S. Pawar, A Socio-demographic profile of Māori living in Australia. NIDEA Working Paper No. 3. Hamilton, New Zealand: University of Waikato, National Institute of Economic and Demographic Analysis, 2013.
[44] United Nations (2007). United Nations Declaration on the Rights of Indigenous Peoples. Accessed online at: http://www. un.org/esa/socdev/unpfii/documents/DRIPS en.pdf.

[45] M. Walter, Lives of Diversity: Indigenous Australians, Australian Academy of the Social Sciences and the Bureau of Statistics Census Project: Canberra, 2008.

[46] SWLASC (2014). 'Noongar Native Title Settlement Information'. South West Land and Sea Council Accessed online at: http://www.noongar.org.au/.

[47] T. Zuberi and E. Bonilla-Silva, White logic, white methods: Racism and methodology. Maryland, USA: Rowman \& Littlefield, 2008.

[48] M. Durie, Race and ethnicity in public policy. Does it work? Social Policy Journal of New Zealand 24 (2005), 1-11.

[49] L. Smith, Decolonising methodologies: Research and indigenous peoples. Dunedin, New Zealand: Otago University Press, 1999.

[50] R. Atkinson, E. Taylor and M. Walter, Burying Indigeneity: The Spatial Construction of Reality and Aboriginal Australia, Social and Legal Studies 19(3) (2010), 311-330.

[51] Australian Bureau of Statistics. (2014). Reconciliation Action Plan 2013-16. Cat. No. 1011.0. Canberra: Australian Bureau of Statistics.

[52] Statistics New Zealand. (2009). Statistics New Zealand's effectiveness for Māori strategy and associated strategic plan 2009-2012. Wellington: Statistics New Zealand.

[53] Statistics New Zealand. (2012). Statement of Intent 2012-17. Wellington: Statistics New Zealand. Accessed online at: http: //www.stats.govt.nz/ /media/Shttp://www.stats.govt.nz/ / media/Statistics/about-us/corporate-publications/statementof-intent $/ 2012 \% 20$-\%202017/statement-of-intent-201217.pdf.

[54] Statistics New Zealand. (2014b). Tatauranga Umanga 2014: Statistics on Māori authorities. Accessed online at: http:// www.stats.govt.nz/browse_for_stats/people_and_communiti es/Māori/tatauranga-umanga-Māori-2014.aspx.

[55] Australian Bureau of Statistics (2012b). ABS Indigenous Community Engagement Strategy. Accessed online at: www. abs.gov.au/websitedbs/corporate.NSF/home/ABS+Indigenou $\mathrm{s}+$ Community+Engagement+Strategy.

[56] Australian Bureau of Statistics (2012c). ABS Indigenous Engagement network. Accessed online at: www.abs.gov.au/web sitedbs/corporate.NSF/home/ABS+Indigenous+Engagement + Network.

[57] K. Jordan, H. Bulloch and G. Buchanan, Statistical equality and cultural difference in indigenous wellbeing frameworks: A new expression of an enduring debate, Australian Journal of Social Issues 45(3) (2010), 333-363.

[58] M. Walter, The 2014 National Aboriginal and Torres Strait Islander Social Survey is an anachronism. On-Line Opinion August, 2013. http://www.onlineopinion.com.au/view.asp?arti cle $=15317$. 